\title{
Humorous Situations Created by Violations and Floutings of Conversational Maxims in a Situation Comedy Entitled How I Met Your Mother
}

\author{
Jenna Nadia Rasbi Putri Amianna \& Adventina Putranti \\ jennarasby@gmail.com \& putranti@usd.ac.id \\ English Letters Department, Universitas Sanata Dharma
}

\begin{abstract}
As a form of communication that evokes laughter, humor is seen as one of important aspects in building relationship with people. Linguists suggest that humor exists because there is noncooperative interaction among interlocutors resulting from not observing Cooperative Principle in the conversations. Related to that, this study aims to analyze humorous situations in a situation comedy entitled How I Met Your Mother Season 2, Episodes 1 to 5 which are created by violating and flouting the conversational maxims as the forms of not observing the Cooperative Principle.
\end{abstract}

Keywords: humorous situation, cooperative principle, flouting, violation

\section{Introduction}

One of the social phenomena found in society dealing with language use in communication is humor. As explained by Holmes \& Marra (2002) humor is a means to improve communication and relationship among speakers and hearers. Humor, as stated in The Oxford American Dictionary and Thesaurus, is "the condition of being amusing or comic." Hence, by having the ability to amuse, humor can create humorous situations. According to Chiaro (1992: 4344), a humorous situation occurs when there is two-faced meaning or ambiguous meaning of linguistic features in a conversation, such as, choice of words. This two-faced meaning is present because the participants in a conversation are probably not cooperative with each other by not following Grice's Cooperative Principle (CP). The participants' attitude for not following the rules of the $\mathrm{CP}$ will create ambiguity and misunderstanding which later can create laughter as one of the effects.
Aside from social interaction, humor can also be found in TV shows. The similarity between humor found in daily interaction and the one that is found in TV shows lies on the principle which creates humor itself. As suggested by Grice, jokes are noncooperative (Attardo, 1994: 271). Taken into account, both humorous situations in daily interactions and in TV shows occur because non-cooperative interactions are found between the interlocutors. The difference between the two lies on the process of the occurrence of the humorous situations. In daily interactions, humorous situations occur naturally in the conversations without being planned by the interlocutors. Meanwhile, the conversations in TV shows are designed by the writer in order to create humorous situations. Even though the conversations in TV shows are designed, they still carry the principle which creates humorous situations.

This study is conducted to examine the humorous situations created by noncooperative interactions in a situation comedy, entitled How I Met Your Mother. In 
this case, the non-cooperative interactions result in violating and flouting of conversational maxims as the sub principles of Grice's Cooperative Principles. The data of this study are obtained from season 2, episodes 1 to 5 . The $2^{\text {nd }}$ season is chosen without any specific purpose since humorous situations are found in all of the 10 seasons.

How I Met Your Mother is an American situation comedy airing from September 19, 2005 to March 31, 2014 which is known best for its eccentric humor and it receives positive reviews over the past view years. IMDB states that the situation comedy is rated 8.4 out of 10 stars for its eccentric humor.

To reach the aim of this study, the writer is summing up into two questions:

1. What are the types of violation and flouting of conversational maxims appear in a situation comedy How I Met Your Mother season 2, episodes 1 to 5 ?

2. How do the violation and the flouting of conversational maxims found create humorous situations in a situation comedy entitled How I Met Your Mother season 2, episodes 1 to 5 ?

In this research, pragmatic approach is applied in order to analyze the violation and flouting of conversational maxims done by the characters in the situations comedy. Grice's Cooperative Principle and its four conversational maxims theories are applied to examine the types of conversational maxims which are violated and flouted by the characters in order to create humorous situations. Furthermore, humor theories are applied in order to analyze how the humorous situations are created by the violation and the flouting of conversational maxims found in this situation comedy.

\section{Meaning in Interaction}

To this day, a number of theories of language have been developed by linguists. One of these theories is pragmatics. Thomas (1995: 22-23) defines pragmatics as meaning in interaction. It takes not only the contributions from the speakers in saying utterances, but also from the hearers in understanding the utterances from their point of view. Besides the contributions from the interlocutors, contexts of utterance, such as physical, social, and linguistic contexts, and the meaning potential of utterance are taken into account in producing meaning. Thus, pragmatics is context-dependent. An utterance cannot be understood separately from the context it is uttered.

\section{Context}

Related to the definition of pragmatics, understanding utterances cannot be separated from the context in which the conversation takes place. In here, context plays an important role in meaning interpretation. Cutting (2002: 3-7) explains that there are three contexts in order to deal with meaning of words in context, which are, situational context, background knowledge context, and co-textual context. The first one, situational context, is "the situation where the interaction is taking place at the moment of speaking" (Cutting, 2002: 4). This context deals with what the speakers and the hearers can see around them. The second one, background knowledge context, contains two types of context; the first one is cultural background context which is dealing with the knowledge that is mutually shared by people in the same community, people in the same country, people in the same school, or people in the same family, and the second one is interpersonal background context which is dealing with "knowledge acquired through previous verbal interactions or joint activities and experiences, and it includes privileged personal knowledge about the interlocutor" (Cutting, 2002: 6). The last one, which is co-textual context, is a type of contexts related only to the context in a text.

\section{Conversational Implicature}

The basic assumption in communication is that when speakers and hearers are engaged in a conversation, they are generally being cooperative with each other. At some point, the meaning of utterances is not conveyed from the 
expressed meaning but from the implied meaning. Something that is more than what the words mean is called an implicature; the additional conveyed meaning of utterances (Yule, 1996: 35). Implicatures are the example of more is being communicated than what is said. Implicatures which occur in conversations and depend on certain context for their interpretation is usually called conversational implicatures.

As stated by Yule (1996: 40-43), there are two types of conversational implicature, they are, generalized conversational implicatures and particularized conversational implicatures. The former is a type of conversational implicature which does not require certain knowledge from a particular context to understand the additional conveyed meanings. There is no special background which is required to create inferences in a conversation, while the latter, is the type of conversational implicature which requires special knowledge of specific context in order to work out the additional conveyed meanings (Yule, 1996: 40-43as seen in the example below:

\section{A : What on earth has happened to the roast beef? \\ B : The dog is looking very happy. \\ (Levinson, 1983: 126)}

In order to make B's answer relevant, A has to draw on some assumed knowledge B expects him to have. It is possible that the dog has eaten the roast beef, thus, it looks very happy.

\section{Cooperative Principle}

When people are engaged in a conversation, they will exchange information with their interlocutors. The basic concept that there will be sufficient amount of information provided in a conversation is one of general idea that the interlocutors will cooperate with each other at the moment they are involved in a conversation. Grice suggests that in order to be cooperative with each other in a conversation, interlocutors should obey the Cooperative Principle which runs as follows:
Make your contribution such as is required, at the stage at which it occurs, by the accepted purpose of direction of the talk exchange in which you are engaged (Thomas, 1995: 61-62).

According to Grice's theory of Cooperative Principle, people should give contribution that is required by the situation, such as, giving sufficient amount of information in a conversation. That being done, the interlocutors are said to be cooperative in making a conversation run smoothly.

Grice suggests that in a conversational interaction, people work on the assumption that a certain set of rules is in operation, unless they receive the indication of the opposite. On one hand, there are times when speakers have indications that the interlocutors obey the same conversational norms as the speakers do. On the other hand, there are times when speakers' assumption that others are cooperating according the same conversational norms is misplaced, since, in fact, the interlocutors turn out to blatantly mislead the speakers by not obeying the conversational norms. In that condition, the speakers are expected to search the implicature might be delivered by the interlocutors.

To avoid a situation when interlocutors blatantly mislead others by not obeying Cooperative Principle, Grice develops four conversational maxims as the sub-principles of the CP. Grice's four conversational maxims are formulated as follows (Thomas, 1995: 63-64):

\section{a. Maxim of Quantity}

i. Make your contribution as informative as is required (for the current purpose of the exchange).

ii. Do not make your contribution more informative than is required.

According to this maxim, speakers should give neither too little nor too much 
information to the interlocutors. When the speakers give too little information, the hearers may not be able to understand what they are talking about due to the hearers' lack of information. Meanwhile, when the speakers give too much information, the conversation may become not effective since the excess information given in the conversation.

\section{b. Maxim of Quality}

i. Do not say what you believe to be false.

ii. Do not say that for which you lack adequate evidence.

This kind of maxim expects the speakers to say anything based on reality. The speakers are not allowed to tell lies to the hearer or to say anything which is far from the truth.

\section{c. Maxim of Relation}

\section{Be relevant}

Due to this maxim, speakers are supposed to say something that is relevant to what has been talked in a conversation. They must give information related to the topic of discussion.

\section{d. Maxim of Manner}

i. Avoid obscurity of expression

ii. Avoid ambiguity

iii. Be brief (avoid unnecessary prolixity)

iv. Be orderly

This last maxim expects the speakers to be brief in saying something. They should avoid saying something which is difficult to understand. At last, the speakers should avoid ambiguity in their utterances. When the speaker fails to obey each rule of the maxim of Manner, it is possible that the hearers also possible to miss the implicatures drawn by the speakers.

\section{Flouting and Violating Conversational Maxim}

According to Grice, flouting a maxim is a situation when "a speaker blatantly fails to observe a maxim" (Thomas, 1995: 65). The speakers do not have any intention to mislead or deceive the hearers, but they expect the hearers to look for the meaning different from, or in addition to, the expressed meaning. The speakers assume that the hearers are able to infer the implied meaning of what is said.

Different from flouting a conversational maxim when the speakers expect the hearers to understand the implied meaning, violating a maxim is a situation when a speaker fails to obey a conversational maxim in order to intentionally generate misleading implicature in a conversation (Thomas, 1995: 73). Speakers are said to violate a conversational maxim when they know that the hearers will not know the truth and will only know the expressed meaning of what is said. In other words, the speakers intentionally mislead and deceive the hearers.

In this research, the writer analyses how the participants in How I Met Your Mother situation comedy flout and violate conversational maxims which lead to the occurrence of humorous situations.

\section{Humor}

Humor is one of the important aspects in building relationship with people. In social relationships, humor plays an important role, which is "measuring mutual understanding about particular topics and signaling good intentions (Kuipers, 2006: 1). The Encyclopedia of Britannica defines humor as a form of communication that evokes the reflex of laughter of people (Benton (ed), 1983: 7).

Many linguists have taken humor as a category which covers "any events or object that elicits laughter, amuses, or is felt to be funny" (Attardo, 1994: 4). By having the 
quality to be funny, humor can create humorous situations. Grice, as cited by Attardo (1994: 271-276), suggests that jokes or humor are non-cooperative. Meaning to say, humorous situations exist because there is non-cooperative interaction among the interlocutors. This non-cooperative interaction occurs because the interlocutors do not obey the CP and its maxims by violating or flouting the rules. By doing so, the humorous situation is created between the speakers and the hearers as the product of violating or flouting the maxims.

Modern theories of humor have been developed by linguists. Raskin, as one of the linguists, classifies humor into three categories, which are, incongruity theory, hostility theory, and release theory (Attardo, 1994: 47). These theories of humor are seen as the common accepted classification of humor. Each of the theory sees humor from different viewpoint.

\section{Incongruity Theory of Humor}

The philosophers who are associated with incongruity theory of humor are Immanuel Kant (1724 - 1804) and Arthur Schopenhauer (1788 - 1860). As cited by Attardo (1994: 48), Kant defines laughter as "an affection arising from sudden transformation of a strained expectation into nothing". The attention will be focused on the sudden transformation, which is the process of how someone's idea about something is transformed, and the fact that the expectation is turned into nothing. Meanwhile, Schopenhauer explains that laughter is caused by "the sudden perception of the incongruity between a concept and the real objects which have been thought through it in some relation, and laughter itself is just the expression of this incongruity" (Schopenhauer, The World as Will and Idea, 1819, quoted in Attardo (1994: 48).

From the explanations above, it can be seen that the basis of the incongruity theory is that humor occurs when there are differences between what is expected and what later occurs. The differences involve the feeling of surprise of the hearers or the audience. This means that humor is the outcome of incongruity created by two conflicting meanings, which are the certain idea that people have in mind and how the idea will create certain expectation as how it will turn out.

The following conversation is a violation of Quantity Maxim found in the situation comedy of How I Met Your Mother in which contains incongruent idea between the speakers' expectation and what actually reveals in the conversation.
Situation:
At the apartment. Robin comes and wants to tell Ted about Lily's getting back in town.

OK, first of all, that is interesting. Second, we have to tell him.

No, we don't. He's just starting to get better. Going out with Barney. How do you think he'll feel when he hears Lily's moved on?

She's moved on?

Well, it happens. I've fallen out of love faster than that before. Sometimes, boom, with no warning whatsoever. One day we're in love, the next day, he's dead to me. But we're great! Honey?

Ted looks confused and shocked. 
In the situation above Robin has violated the maxim of Quantity. She provides too much information that what is required in the conversation. This can be seen from her answer to Ted. Ted questions Robin about whether or not Lily has moved on and her answer is, "Well, it happens. I've fallen out of love faster than that before. Sometimes, boom, with no warning whatsoever. One day we're in love, the next day, he's dead to me. But we're great! Honey". In here, Robin's answer contains information that is not requested in the situation. The unnecessary information is about her personal love experience which is actually not the information expected by Ted. Robin could have just told him Lily's condition at that time.

To understand how this violation of Quantity maxim creates humorous situations, incongruity theory of humor is applied in the analysis. Related with incongruity theory of humor, humorous situation occurs because there are two conflicting meanings that occur in the conversation. In the situation above, the two conflicting meanings are Ted expectation of Robin's answer about Lily's condition and the actual answer he gets from Robin. In the conversation, Ted asks Robin about Lily's condition after breaking up with Marshall and whether or not she has moved on. He expects Robin to give sufficient answer based on his question. In fact, instead of giving him sufficient information about Lily, Robin gives information about her own love experience about how she handles a break up with her ex-boyfriend which is not appropriate in the exchange of information. She even explains it enthusiastically without realizes that she provides unnecessary information to Ted. This unnecessary information from Robin is not expected by Ted and the audiences. Thus, Robin's unexpected answer shows her absurd and ridiculous action. Her ridiculous action is the result of her unawareness of Ted's expectation. In conclusion, the transformation of the idea expected by the audiences and what actually turns out in the conversation makes the audiences' expectation vanish and creates discrepancy which arouses laughter.

Another humorous situation containing incongruent idea also appears in the following conversation where the character flouts Maxim of Manner:

\begin{tabular}{|l|l|}
\hline \multicolumn{2}{|l|}{$\begin{array}{l}\text { Situation: } \\
\text { In a strip-club, Barney gets a call from Ted. }\end{array}$} \\
\hline Barney & Barney. \\
\hline Ted & Uh, hey. Where are you guys? \\
\hline Barney & $\begin{array}{l}\text { We're at a fundraiser helping } \\
\text { young women raise money for } \\
\text { college. }\end{array}$ \\
\hline Ted & Strip-club. Nice. Is Marshall OK? \\
\hline
\end{tabular}

The excerpt above is taken at the situation when Ted and Robin are on their way to Montauk. During the trip, Ted calls Barney to check on Marshall. Ted asks Barney where they are at that time. Without any doubt, Barney answers him by saying, "We're at fundraiser helping young women raise money for college". After listening to Barney's answer, Ted directly knows that Barney and Marshall are in a strip-club. Ted knows that both of them are not really at a fundraiser. In here, it can be seen from Barney's answer that he has flouted the maxim of manner. Barney's answer is ambiguous and he intentionally says that to trick Ted and let him figure out the actual meaning of his statement. Instead of giving ambiguous statement, Barney could have just said, "We are in a strip club" to Ted directly.

This is another flouting containing incongruent idea between people's expectation and what it actually occurs in the conversation. To understand how this flouting of maxim of Manner creates humorous situations, incongruity theory of humor is also applied in the analysis. Related with incongruity theory of humor, humorous situation occurs because there are two conflicting meanings that occur in the conversation. In the situation above, the two conflicting meanings are the audiences' expectation of Barney's answer to Ted and 
the actual answer Ted gets in the conversation.

\section{Hostility Theory of Humor}

Hostility or Superiority Theory is an earliest theory of humor which can date back to Aristotle's and Plato's works. This theory mentions the negative element of humor, which is its aggressive side (Attardo, 1994: 49). That aggressive side can be seen as the negative side of humor which is mainly used to humiliate, disparage, or ridicule others' inferiority or misfortunes. Both Aristotle and Plato emphasize that laughter is a means of power when it is directed against others' faults or flaws, so that it will show someone's superiority among the victims. Thomas Hobbes, as a philosopher, suggests that "laughter arises from a sense of superiority of the laugher towards some object" (Attardo, 1994: 49). In that case, "some object" commonly refers to the "butt of the joke"; anything that is being laughed at. As stated in Moreall (1987: 20), Hobbes uses the term "sudden glory" to indicate the expression arising from comparing someone's superiority with others' weaknesses.

From the explanations above, according to hostility theory, humor is created when there is a sudden glory as the expression when someone is being superior among others. The feeling of superiority appears when someone laughs, mocks, or humiliates at others' inferiority, weaknesses, stupidity, or misfortunes.

The conversation bellow shows a humorous situation in the form of sudden glory which is created by flouting Quality maxim.

\begin{tabular}{|l|l|}
\hline Ted & Hey. \\
\hline Robin & Hey. \\
\hline Ted & How was your day? \\
\hline Robin & Good. \\
\hline Ted & $\begin{array}{l}\text { Wow, you're a great interviewer. Aren't you gonna ask how my day } \\
\text { was? }\end{array}$ \\
\hline Robin & $\begin{array}{l}\text { No, I know how it was. It was awful. Ooh, you want to rent a } \\
\text { movie tonight? }\end{array}$ \\
\hline Ted & You know, um... I listen to your work stories all the time. \\
\hline Robin & $\begin{array}{l}\text { Yeah, but... and I don't want to be rude here, but my work stories } \\
\text { are interesting. I'm a television news reporter. }\end{array}$ \\
\hline
\end{tabular}

The situation above is when Robin just goes back from working and Ted is waiting for her at the apartment.

In that situation, Ted asks Robin how her day was, and she answers that it was good. According to Ted, Robin's response is not like the way he wants. Robin provides less information than what he expects. Further, since Robin does not ask Ted about his work stories, Ted asks Robin again by directly saying, "Aren't you gonna ask how my day was?", then she answers, "No, I know how it was. It was awful". In fact, Robin has no idea how Ted's job is. She never asks Ted about his job or what he does in the office. She does not truly understand about Ted's job yet she still says that his job is awful. Her answer is only based on her own opinion which shows her lack of adequate information about Ted's job. Providing any opinion without the foundation of adequate information is the fact that Robin has flouted the maxim of Quality. Before making any assumption, it is better for her to know the environment of Ted's job.

In the situation above, laughter arouses when Robin flouts the maxim of Quality, 
which is when she mocks Ted's job as an awful job. Linked to hostility theory, Robin's action is seen as an action of being hostile. According to the theory, humor is created when someone is laughing at others in an attempt to humiliate or ridicule their inferiority or misfortunes. People who are treated as the inferiors will be the butt of the joke. In the situation above, Robin's answer to Ted is seen as the form of humiliation to Ted, and in this case, Ted is seen as the butt of the joke. Laughter arouses when there are pleasure and glorious feelings created from being superior to Ted.

Another humorous situation containing an act of being hostile can also be found in the following conversation where the character flouts Maxim of Manner:

\begin{tabular}{|l|l|}
\hline Marshall & $\begin{array}{l}\text { Lily is evil! She just wore that dress to torture me. Well, you know what? Two } \\
\text { can play at that game. See, at brunch, I'm going to torture Lily right back. } \\
\text { Yeah. There's a part of my body that she's got a weakness for, too. }\end{array}$ \\
\hline Barney & Dude, you can't whip that out at brunch. \\
\hline Marshall & No, not that. I'm going to unleash my calves. \\
\hline Barney & $\begin{array}{l}\text { That's crazy. Nobody's turned on by men's calves. They're a thoroughly } \\
\text { unerotic body part. }\end{array}$ \\
\hline Marshall & Well, yeah, I'd say that, too, if I had those skinny little chicken legs. \\
\hline Barney & I'll be waiting by the phone for your apology. \\
\hline
\end{tabular}

In the conversation above, Marshall has a fight with Barney. In the beginning, Marshall tells Barney about his plan to take revenge to Lily by showing his body part that he is sure will seduce her. That body part is his calves. To respond Marshall's plan, in disbelief Barney says, "That's crazy. Nobody's turned on by men's calves. They're a thoroughly unerotic body part." Barney's answer is ambiguous and it carries deeper meaning which he thinks that calves are uninterested body parts that no one will be paying attention to. He even uses the word 'unerotic' which is a word invented by himself to describe calves.

Offended by Barney's statement, Marshall abruptly says, "Well, yeah, I'd say that, too, if I had those skinny little chicken legs." As explained previously, Marshall has flouted the maxim of Manner by uttering that statement. Marshall hopes that Barney gets the implicature he delivers which is that Barney's thin legs. Regarding his reply to Barney, Marshall's statement contains humiliation addressed to Barney. He mocks Barney's legs for being too thin, especially because they look like chicken legs. According to hostility theory, Marshall's action is seen as an act of being superior and Barney is seen as the inferior. As the victim, he becomes the butt of the joke. Glorious feeling occurs when Marshall mocks Barney for having checks like chicken. That glorious feeling creates laughter in the situation.

\section{Release Theory of Humor}

Release theory of humor is basically based on the idea that humor is used to release tension or psychic energy (Attardo, 1994: 50). Once the tension is released, someone will feel liberated. According to this theory, in order to deal with an upcoming social or psychological event, emotional tension is built. When there is excess energy in one's mind, the surplus energy is dispelled through laughter. The most influential proponent of this theory is Sigmund Freud. As quoted by Schwarz (2010: 51), he considers laughter as "an outlet for psychic or nervous energy".

According to Freud, relating to his analysis of humor, he suggests two forms of joking, which are "innocent" and 
"tendentious" jokes. On one hand, innocent joke is known as innocent humor. Instead of threatening people, this type of joke tends to elicit enjoyment of the content. Freud states that there is no fear of judgment being disturbed by the content or purpose of the jokes (Schwarz, 2010: 55).

On the other hand, tendentious joke is a joke which describes an event that commonly shock or terrify the audience. It functions either to express hostility and aggressiveness or obscenity and exposure. $\mathrm{He}$ argues that in tendentious joke, unconscious thought is responsible for releasing joke due to the repressed feeling. In that case, pleasure arises from the hidden aggression or hostility one feels towards people who have more power than him.

In conclusion, release theory of humor is a theory which sees humor as a means to release tension and energy someone has as the effect of being controlled and suppressed by circumstances or thoughts. People, then, get liberated by bursting out laughter in order to release the tension.

Below is a conversation when a humorous situation is created by releasing emotions as the character is violating the maxim of Relation.

\begin{tabular}{|c|c|}
\hline \multicolumn{2}{|c|}{$\begin{array}{l}\text { Situation: } \\
\text { Ted, Robin, Marshall, Lily, and Barney are } \\
\text { having brunch with Ted's parents. In the } \\
\text { middle of it, Lily and Marshall are having a } \\
\text { quarrel about who seduces who. }\end{array}$} \\
\hline Lily & $\begin{array}{l}\text { Just admit it. You came here } \\
\text { trying to seduce me. }\end{array}$ \\
\hline Marshall & Seduce you \\
\hline Lily & $\begin{array}{l}\text { You sat down next to me and } \\
\text { took most of your pants off. }\end{array}$ \\
\hline Marshall & $\begin{array}{l}\text { You went to San Francisco for } \\
\text { three months. }\end{array}$ \\
\hline Lily & How is that seducing you? \\
\hline Mars & $\begin{array}{l}\text { Well, it's not but I'm still mad } \\
\text { about it. }\end{array}$ \\
\hline
\end{tabular}

Above is a situation when Marshall is having a fight with Lily. They are arguing about who is seducing who. Lily accuses Marshall for seducing her and vice versa. In the middle of the fight, Marshall says, "You went to San Francisco for three months." As explained in the previous subchapter, his response above is not related to the topic of discussion they are having. He does that because he still cannot accept the fact that his wedding with Lily is canceled due to the fact that Lily flies to San Francisco in order to chase her dream. Thus, he changes the topic of discussion intentionally and blames Lily all over again for leaving him. Marshall's statement above can be seen as a violation of maxim of Relation.

In here, release humor theory is applied in order to see how the humorous situation is created by the violation of maxim of relation. In the situation above, humor arouses when Marshall violates the maxim of relation, which is the moment when he suddenly changes the topic of discussion by mentioning Lily's journey to chase her dream in San Francisco. That statement represents Marshall's anger towards Lily that he still keeps even until after Lily gets back in town. According to release theory of humor, humor is created when someone attempts to release particular emotion and feelings in his mind in order to be free from that emotion. Marshall's action above can be seen as an attempt to release the pain he carries in his mind. Thus, when he releases his emotion, laughter occurs.

\section{Conclusion}

In this research, after analyzing the conversations, there are found fourteen violations of maxim of Quantity, one violation of maxim of Quality, two violations of maxim of Relation, and two violations of maxim of Manner in the selected season of How I Met Your Mother situation comedy. The violations are created because the characters in the situation comedy intentionally mislead and deceive the interlocutors by generating misleading implicatures in a conversation. 


\begin{abstract}
Different from violations of conversational maxim, flouting of conversational maxims as seen in the situation comedy occurred because the characters in the situation comedy do not intentionally mislead and deceive the interlocutors. They expect the interlocutors to be able to look for the meaning different from, or in addition to, the expressed meaning. The speakers assume that the hearers are able to infer the implied meaning of what is said.
\end{abstract}

From both of the data findings, it can be concluded that the characters in the situation comedy entitled How I Met Your Mother have violated and flouted conversational maxims.

For the second problem of this research, the writer concludes that the humorous situations are created by the violation and the flouting of conversational maxims done by the characters in the situation comedy. From the analysis, there are three different ways of how the humorous situations are created. First, the humorous situations are created because some of the violation and the flouting of conversational maxims contain incongruent idea between people's expectation and what actually occurs in the conversation between the interlocutors. This result is obtained by applying incongruity theory of humor which sees humor as the outcome of two conflicting meanings. Second, the humorous situations occur because some of the violation and the flouting of conversational maxims contain the acts of being hostile to someone else; especially by mocking or humiliating other's inferiority. This result is obtained by applying hostility theory of humor to the violation and flouting found in the situation comedy. According to hostility theory of humor, humor is created when there is a sudden glory as the expression when someone is being superior among others. Third, the humorous situations occur because some violation and flouting contain particular released emotions of the characters which elicit laughter. This result is obtained by applying release theory of humor.

\section{References}

Attardo, Salvatore. Linguistic Theory of Humor. Berlin and New York: Mouton de Gruyter, 1994.

Benton, H. (ed.). The New Encyclopedia Britannica: Macropedia Knowledge in Depth Volume 9. Chicago: William Benton Pub., 1983.

Chiaro, Delia. The Language of Jokes: Analysing verbal play. London and New York: Routledge, 1992.

Cutting, Joan. Pragmatics and Discourse: A Resource Book for Students. London: Routledge, 2002.

Fromkin, Victoria, Robert Rodman, and Nina Hyams.An Introduction to Language: $7^{\text {th }}$ edition. Massachusetts: Thomson Corporation, 2003.

Holmes, Janet and Meredith Mara."Over the edge?Subversive humor between colleagues and friends".Humor. Vol.15.No.1 (2002): pp. 65-87.

Jafari, Janin. "The Pragmatic Analysis of Wilde's Comedy: The Importance of Being Ernest". Theory and Practice in Language Studies. Vol.3 No.12 (December 2013): pp. 2152-2156.

Kuipers, Giselinde. Good Humor, Bad Taste: A Sociology of the Joke. Berlin: Mouton de Gruyter, 2006.

Leech, Geoffrey. Principles of Pragmatics. London and New York: Longman, 1983.

Levinson, Stephen C. Pragmatics. Cambridge: Cambridge University Press, 1983.

Morreall, John (ed.). The Philosophy of Laughter and Humor. Albany: State University of New York Press, 1987.

Palupi, Sri Retno. An Analysis of Humor Types and Grice's Maxim in the Situation Comedy Friends Episode of "The One with That Could Have Been" (A Pragmatic 
Approach). Undergraduate thesis. Surakarta: University of Sebelas Maret, 2006.

Savorelli, Antonio. Beyond Sitcom: New Directions in American Television Comedy. New York: McFarland \& Company, Inc., 2010.

Schwarz, Jeannine. Linguistic Aspects of Verbal Humor in Stand-up Comedy.Dessertation.Saarbrücken: der Universität des Saarlandes, 2010.

Shade, Richard A. License to Laugh: Humor in the Classroom. New York: Teacher Ideas Press, 1996

Thomas, Jenny. Meaning in Interaction: An Introduction to Pragmatics. New York: Routledge, 1995

Wood, Linda A. and Rolf O. Kroger.Doing Discourse Analysis: Methods for studying action in talk and text.California: Sage Publications, Inc., 2000.

Wu, Yu-wen and Yong Chen. "Humor Strategies in the American Sitcom "Friends: An Empirical Study with Reference to Grice's Cooperative Principle" in [Department of English] Proceedings. Pingtung City: National Pingtung University of Education, 2010.

Yule, George. Pragmatics. Oxford: Oxford University Press, 1996. 